\title{
Effect of Chia Seed Oil (Salvia hispanica L.) on Cell Viability in Breast Cancer Cell MCF-7 ${ }^{+}$
}

\author{
Armando M. Martín Ortega and Maira Rubí Segura Campos* \\ Facultad de Ingeniería Química, Universidad Autónoma de Yucatán, Periférico Norte Km. 33.5, \\ Tablaje Catastral 13615, Col. Chuburná de Hidalgo Inn, Mérida, Yucatán C.P. 97203, Mexico; \\ armandomarorte@gmail.com \\ * Correspondence: maira.segura@correo.uady.mx \\ + Presented at the 2nd International Conference of Ia ValSe-Food Network, Lisbon, Portugal, \\ 21-22 October 2019.
}

Published: 1 September 2020

\begin{abstract}
Worldwide, cancer represents one of the main causes of mortality and morbidity, with breast cancer being the most diagnosed and the main cause of mortality among women. The purpose of this study is to evaluate the effect of chia seed oil on cell viability in the breast cancer line MCF-7. Tumor cells were treated to various concentrations of chia seed oil (12.5-400 $\mu \mathrm{g} / \mathrm{mL})$, then cellular viability was evaluated by (3-(4,5-dimethyl thiazole-2yl)-2,5-diphenyl tetrazolium bromide) MTT assay. Cellular viability was increased in the highest concentration group. Chia seed oil in high concentrations could potentially increase the viability of breast cancer cells.
\end{abstract}

Keywords: alternative; cancer; chia; nutraceutical; nutrition; oil

\section{Introduction}

Cancer is one of the main public health problems worldwide and represents the third leading cause of death in Mexico. Moreover, its incidence is increasing, without discriminating against countries or regions [1,2]. At the same time, national and international efforts to find more effective and less harmful treatments have been increased, including the investigation of bioactive compounds derived from food $[3,4]$.

In addition to being an energy and structural source for the human body, fatty acids are bioactive lipids that regulate a large number of cellular processes, including growth regulation, apoptosis and cell proliferation $[5,6]$. Several in vitro and in vivo studies with isolated fatty acids and food oils have shown to have both anti-cancer and carcinogenic effects [7-10]. Thus, demonstrating an important role in the prevention and treatment of cancer. For its part, chia seed is an important source of $\omega-3$ polyunsaturated fatty acids, and is considered a functional food because of its ability to exert antiinflammatory, lipid-lowering, anti-hyperglycemic and metabolic regulating effects that are important in the treatment of chronic diseases, mainly metabolic [11,12]. Moreover, at present, there are international collaborations (Chia-Link International Network) for continuous research on the potential health benefits of chia seed, and the development of the functional foods derived from it.

The study of the effect of chia seed oil on cancer cells, would allow us to know its anti-cancer or carcinogenic potential, which would provide a basis for further studies in in vivo and clinical models. Likewise, the results of this study would serve as a guide for conducting studies of other oils, increasing the knowledge of the relationship between food and cancer, ultimately for the improvement of nutritional interventions in this disease. 


\section{Materials and Methods}

\subsection{Seed Oil Extraction}

Dried whole seeds without mucilage were pressed in a cold pressing system until the oil was extracted, using a pressure of $8 \mathrm{ton} / \mathrm{m}^{2}$. The extracted oil was stored in an amber glass container inside a refrigerator at $4{ }^{\circ} \mathrm{C}$ away from the light, to allow sedimentation of seed residues and subsequent removal by centrifugation.

\subsection{Chemical Oil Hydrolysis (Ethanolysis)}

To obtain the free fatty acids (FFA), Salvia hispanica L. oil was chemically hydrolyzed by an alkaline hydrolysis with $\mathrm{KOH}$ and ethanol, following the methodology proposed by Riss et al. (2013). Then, $25 \mathrm{~g}$ of oil was mixed with $150 \mathrm{~mL}$ of $1 \mathrm{M} \mathrm{KOH}(95 \% \mathrm{EtOH})$ and placed in a $65^{\circ} \mathrm{C}$ water bath for $2 \mathrm{~h}$. Subsequently, to stop the hydrolysis, $100 \mathrm{~mL}$ of distilled water was added to the mixture. The non-hydrolyzed portion was removed by extraction with $100 \mathrm{~mL}$ of hexane. The aqueous alcohol phase, which contained the FFA, was acidified to $\mathrm{pH} 1$ with $6 \mathrm{~N} \mathrm{HCl}$ to remove $\mathrm{K}$ from the carboxyl groups of fatty acids $(\mathrm{R}-\mathrm{COOK}+\mathrm{HCl} \rightarrow \mathrm{R}-\mathrm{COOH}+\mathrm{KCl})$. The resulting free fatty acids were recovered by extraction with hexane and distilled water was added until a neutral $\mathrm{pH}$ was obtained. The phases formed by the mixture of water and hexane were separated with a separating funnel. Finally, the upper portion, which contains the FFA, was dried with anhydrous magnesium sulfate and the solvent was evaporated with a broken steam under vacuum at $35^{\circ} \mathrm{C}$ [13].

\subsection{Determination of the Fatty Acid Profile by Gas Chromatography}

The composition of fatty acids was determined using the methodology proposed by Us-Medina (2015) with some modifications. First, $50 \mathrm{mg}$ of oil was taken in a $50 \mathrm{~mL}$ test tube, $10 \mathrm{~mL}$ of $10 \% \mathrm{w} / \mathrm{v}$ $\mathrm{KOH}$ in a methanol solution was added and allowed to reflux for $45 \mathrm{~min}$ in a controlled temperature bath $\left(60^{\circ} \mathrm{C}\right)$. At the end of the saponification, the sample was washed three times with $3 \mathrm{~mL}$ of hexane. Next, $2 \mathrm{~mL}$ of concentrated $\mathrm{HCl}$ was added and the fatty acids were extracted with three $2 \mathrm{~mL}$ portions of hexane, followed by drying with a nitrogen flow. Subsequently, a transesterification of the sample was performed by adding $420 \mu \mathrm{L}$ of $5 \% \mathrm{HCl}$ in a methanol solution to the fatty acids, then refluxing at $85{ }^{\circ} \mathrm{C}$ for $150 \mathrm{~min}$ in a controlled bath. The result of the transesterification was methyl fatty acid esters (FAME), which were extracted with three $2 \mathrm{~mL}$ portions of hexane. Then, $80 \mu \mathrm{L}$ of a 10,000-ppm solution of the C17 standard in hexane was added. The hexenic phase was dried by a stream with nitrogen. After drying, the FAME were reconstituted with $1 \mathrm{~mL}$ of hexane to be injected into the chromatograph in split 25:1 mode with Helium (analytical grade) as the mobile phase. The gas chromatograph that was used is an Agilent Technologies 6890N, with an SP-2560 column, $100 \mathrm{~m}$ long, $0.25 \mathrm{~mm}$ internal diameter and $0.20 \mu \mathrm{m}$ thick. The conditions that were used are: injector temperature of $250{ }^{\circ} \mathrm{C}$, column flow of 1.0 , oven temperature of $140^{\circ} \mathrm{C}$ for $5 \mathrm{~min}$ and increased to 240 ${ }^{\circ} \mathrm{C}$ in a gradient of $4{ }^{\circ} \mathrm{C} / \mathrm{min}$, with a mass detector.

\subsection{Evaluation of Cytotoxic and Antiproliferative Activity In Vitro}

The cytotoxic and antiproliferative activities of the hydrolyzed oil were carried out by culturing the cell line with different concentrations of chia seed oil leaving them with the treatment for $48 \mathrm{~h}$. The negative control was the cell line cultured only with the culture medium, while for the positive control Taxol was used, a drug commonly used in cancer chemotherapy and in vitro studies. At the end of the treatment, the MTT assay (3-(4,5-dimethylthiazol-2-yl)-2,5-diphenyl-tetrazolium bromide) was performed to evaluate cell viability (explained below).

\subsubsection{Preparation of the Compounds}

The hydrolyzed oil was prepared at different concentrations for evaluation. A stock of $4 \mathrm{mg} / \mathrm{mL}$ of each compound was prepared by diluting $20 \mathrm{mg}$ of the compound in $5 \mathrm{~mL}$ of fresh medium and subsequently passed through a $0.2 \mu \mathrm{m}$ pore size nylon membrane syringe filter (cat. 431224, Corning, 
Monterrey, NL, Mexico). Serial dilutions were being made from the stock with the culture medium until concentrations of 12.5, 25, 50, 100, 200 and $400 \mu \mathrm{g} / \mathrm{mL}$. These dilutions were prepared immediately before use.

\subsubsection{Cell Culture}

Cells were grown in Dulbecco's Modified Eagle Medium (DMEM/F-12) medium without phenol red (cat. D2906, Sigma Aldrich, St. Louis, MO, USA) supplemented with 1.2 g/L NaHCO 3 (cat. S5761, Sigma Aldrich, St. Louis, MO, USA) and 10\% phosphate buffered saline (PBS) (cat. 10437028, Invitrogen, Carlsbad, CA, USA). The cells were incubated at $37{ }^{\circ} \mathrm{C}$ with $5 \% \mathrm{CO}_{2}$ and a humidified atmosphere, in a Lab-Line incubator (Barnstead, Melrose Park, IL, USA). Each time the cell culture reached about $70-80 \%$ confluence, subcultures were performed.

\subsubsection{Cell Count and Viability}

The cell count was performed with the Neubauer chamber and the determination of cell viability by the trypan blue exclusion technique.

For this procedure, a $200 \mu \mathrm{L}$ sample of the suspended cells was taken, $20 \mu \mathrm{L}$ of trypan blue was added, placed in a Neubauer chamber and observed under a microscope. Dead cells have a blue color. A concentration of cells was satisfied per $\mu \mathrm{L}$, counting the living cells.

\subsubsection{Evaluation of Cytoxicity and Antiproliferative Effect by the MTT Technique}

The determination of cellular cytoxicity/antiproliferative was performed using the MTT technique. This technique allows the proliferation to be measured indirectly by the detection of the coloration caused by the metabolic reduction in the tetrazolium salt bromide of 3-(4,5dimethylthiazol-2-yl)-2,5-diphenyltetrazolium (MTT), yellow, due to the action of mitochondrial dehydrogenase enzymes, so only viable cells can reduce it. The resulting compound, formazan blue, can be solubilized and quantified spectrophotometrically [14].

\subsubsection{Procedure}

The procedure performed is described below.

1. For each cell line, the cells were shown to have viability greater than $95 \%$ and were inoculated in 96-well plates (cat. 83.1835, Sarstedt, Newton, NC, USA). To each well was added $100 \mu \mathrm{L}$ of prepared cell suspension at $1 \times 10^{5} \mathrm{cell} / \mathrm{mL}$ in DMEM/F-12 medium. Some wells were inoculated with culture medium only for control. The plate edge wells were inoculated with 1XPBS to prevent an evaporation of the samples.

2. After inoculation, the cells were incubated at $37{ }^{\circ} \mathrm{C}$ with $5 \% \mathrm{CO}_{2}$ for $24 \mathrm{~h}$.

3. After $24 \mathrm{~h}$, the medium was removed and $100 \mu \mathrm{L}$ of the dilutions of the compounds per well (triplicate) were added. The final concentrations in the wells were: 12.5, 25, 50, 100, 200 and 400 $\mu \mathrm{g} / \mathrm{mL}$. Then, $100 \mu \mathrm{L}$ of the culture medium was added to the controls of the cells without compounds and the medium without cells. The plates were incubated for $48 \mathrm{~h}$.

4. At the end of the incubation period, the wells of the plates were visualized under a microscope to verify that there was no visible contamination.

5. A wash with $1 X$ PBS was performed on all wells and left with $100 \mu \mathrm{L}$ of $1 \mathrm{X}$ PBS.

6. Subsequently, $10 \mu \mathrm{L}$ of the MTT reagent $(5 \mathrm{mg} / \mathrm{mL}$, cat. M5655 Sigma Aldrich, St. Louis, MO, USA) was added to each well and incubated for $3 \mathrm{~h}$.

7. Next, $100 \mu \mathrm{L}$ of isopropanol/DMSO (1:1) was added to each well and vigorously resuspended to solubilize the formazan crystals.

8. Finally, the plates were read on a microplate spectrophotometer at a wavelength of $590 \mathrm{~nm}$.

9. The percentage of cell proliferation ( $\% \mathrm{P})$ was calculated, with respect to the control, with the following formula:

$$
\% \mathrm{P}=(\mathrm{ODw} / \text { compound }) /(\mathrm{OD} \text { control }) \times 100
$$


where:

ODw/compound: optical density of cells with compound.

OD control: optical density of the cell control (cells without compounds).

\subsection{Statistical Analysis}

All results were processed using descriptive statistics using measures of central tendency (mean) and dispersion (standard deviation). The data obtained from the biological activities were evaluated by means of one-way analysis of variance and a comparison of means (Student's T method) to establish statistical differences between treatments with a 95\% confidence level $(p<0.05)$.

\section{Results and Discussion}

\subsection{Gas Chromatography}

The results of the gas chromatography demonstrated the presence of palmitic acid $(7.7 \pm 0.19 \%)$, stearic $(4.45 \pm 0.15 \%)$, oleic $(9.57 \pm 0.27 \%)$, arachidonic $(0.30 \pm 0.00 \%)$, linoleic $(20.56 \pm 0.14 \%)$ and alpha-linolenic $(57.29 \pm 0.07 \%)$. The fatty acid present in a greater proportion was alpha-linoleic acid, which is considered an essential fatty acid, and omega 3 . The content of the latter is lower compared to that reported from other crops of Mexican origin [15]. However, it is known that the chemical composition of the seed is variable and depends on the region where it grows, with elevation above sea level being a determining factor.

\subsection{Cell Viability Assay}

Cellular viability was $159.8 \pm 4.5 \%(p=0.01), 144.4 \pm 3.6 \%(p=0.01), 109.5 \pm 2.9 \%(p=0.06), 105.1$ $(p=0.09), 97.4 \pm 3.1 \%(p=0.31)$ and $91.8 \pm 5.1 \%(p=0.04)$ for $400,200,100,50,25$ and $12.5 \mu \mathrm{g} / \mathrm{mL}$ of chia oil, respectively, compared with cells without treatment (control group: culture medium) (Figure 1). Cellular viability was significantly increased in the two major concentrations of the oil (400 and $200 \mu \mathrm{g} / \mathrm{mL})$ and reduced in the lower concentration of the oil $(12.5 \mu \mathrm{g} / \mathrm{mL})$.

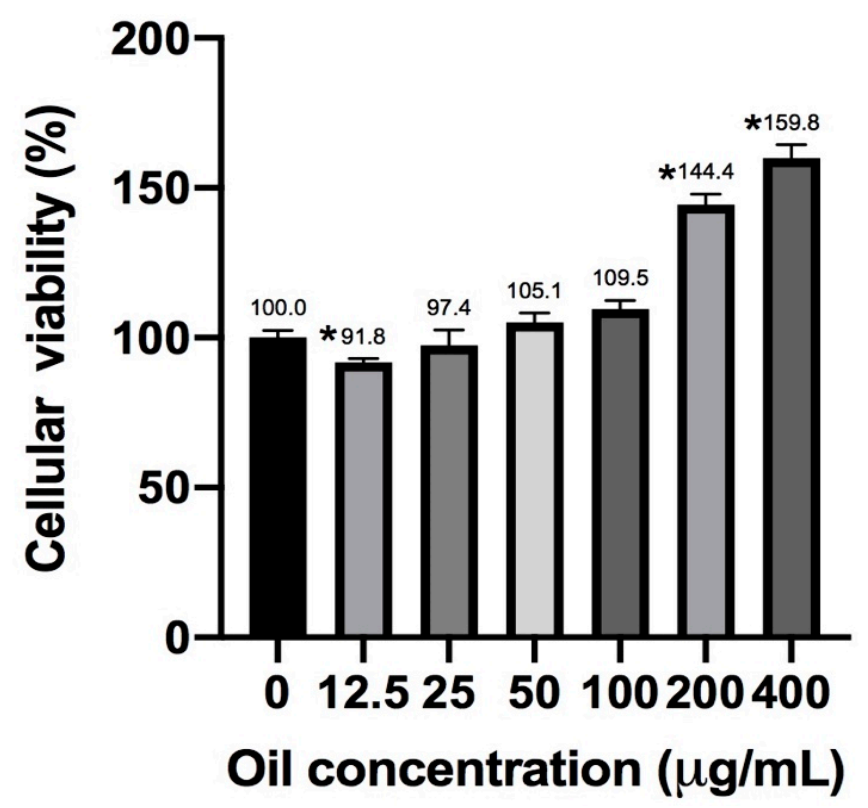

* Statistically significant

Figure 1. Cellular viability assay results.

The lower concentration $(12.5 \mu \mathrm{g} / \mathrm{mL})$ significantly reduced cell viability compared to the control. However, concentrations greater than $50 \mu \mathrm{g} / \mathrm{mL}$ increased cell viability. The two highest concentrations significantly increased cell viability. These results are due to the fact that alpha linolenic acid (omega 3) 
has antitumor potential, and at low concentrations $(\leq 25 \mu \mathrm{g} / \mathrm{mL})$ of chia oil its effect was prevalent. However, at high concentrations $(>25 \mu \mathrm{g} / \mathrm{mL}$ ) of the oil, the concentrations of linoleic acid (omega 6) are increased, which has been shown to increase the cell proliferation of breast cancer cells. In turn, it is important to consider that different studies have found an antitumor effect of alpha linolenic acid in various cell lines, including breast, colon and prostate cancer [16-18], while linoleic acid has demonstrated inverse effects, increasing the proliferation of breast cancer cell lines [19-21].

It is important to consider that the effects demonstrated in the in vitro study of the oil are not extrapolated at the systemic level, this is due to the possible metabolism and absorption of fatty acids by other organs before reaching the breast tissue. On the other hand, Espada et al. (2007) evaluated the effect of Salvia hispanica and Carthamus tinctorius oil on eicosanoid production, growth and metastasis in a murine model of mammary gland adenocarcinoma. This study found that the diet with chia oil produced a reduction in the amount of arachidonic acid and eicosanoids in the neoplasic cells $(p<0.05)$, as well as in the weight and number of tumor metastases $(p<0.05)$, compared with the Carthamus tinctorius diet and control diet. In addition, animals fed with chia oil showed a greater infiltration of $\mathrm{T}$ lymphocytes and apoptosis of the tumor cells with respect to the other diets $(p<0.05)$. Thus, the study authors concluded that Salvia hispanica oil is a rich source of polyunsaturated fatty acids $\omega-3$ with the potential to inhibit tumor growth and metastasis, at least in the murine model [8].

Interestingly, other studies conducted with seed oils such as flaxseed, canola, walnut, squash and neem, have found growth-inhibiting effects of various cancer cell lines [22-25]. In addition to the potential regulatory effect of fatty acids in oils, it is possible that the presence of phytochemicals may be contributing to the antitumor effects. However, in the case of the present study, it is likely that the linoleic acid content of chia seed oil has been the main contributor to the increase in cell viability at higher concentrations.

\section{Conclusions}

This study suggests that chia seed oil in high concentrations could potentially increase the viability of breast cancer cells. However, at low concentrations it could reduce cell viability. Thus, future research is necessary, specifically as regards employing the isolates of omega 6 and omega 3 to extend beyond our concluded results.

Funding: This work was supported by grant Ia ValSe-Food-CYTED (119RT0567).

\section{References}

1. Stewart, B.W.; Wild, C.P. World Cancer Report 2014; World Health Organization: Geneva, Switzerland, 2014, doi:9283204298.

2. INEGI. Estadísticas a Propósito del día Mundial Contra el Cáncer (Comunicado de Prensa Number 61/18); Instituto Nacional de Estadística y Geografía: Aguascalientes City, Aguascalientes, Mexico, 2017. Available online: https://www.inegi.org.mx/contenidos/saladeprensa/aproposito/2018/cancer2018_nal.pdf (accessed on 1 September 2019).

3. Hudson, T.J.; Anderson, W.; Aretz, A.; Barker, A.D.; Bell, C.; Bernabé, R.R., Wainwright, B.J. International network of cancer genome projects. Nature 2010, 464, 993-998, doi:10.1038/nature08987.

4. Pratheeshkumar, P.; Son, Y.O.; Korangath, P.; Manu, K.; Siveen, K. Phytochemicals in cancer prevention and therapy. BioMed Res. Int. 2015, 8, 324021, doi:10.1155/2015/324021.

5. Michalak, A.; Mosińska, P.; Fichna, J. Polyunsaturated fatty acids and their derivatives: Therapeutic value for inflammatory, functional gastrointestinal disorders, and colorectal cancer. Front. Pharmacol. 2016, 7, 459, doi:10.3389/fphar.2016.00459.

6. Gu, Z.; Suburu, J.; Chen, H.; Chen, Y.Q. Mechanisms of omega-3 polyunsaturated fatty acids in prostate cancer prevention. BioMed Res. Int. 2013, 2013, 824563, doi:10.1155/2013/824563.

7. Corsetto, P.A.; Montorfano, G.; Zava, S.; Jovenitti, I.E.; Cremona, A.; Rizzo, A.M. Effects of n-3 PUFAs on breast cancer cells through their incorporation in plasma membrane. Lipids Health Dis. 2011, 10, 73, doi:10.1186/1476-511X-10-73. 
8. Espada; C.E.; Berra, M.A.; Martinez, M.J.; Eynard, A.R.; Pasqualini, M.E. Effect of Chia oil (Salvia hispanica) rich in $\omega-3$ fatty acids on the eicosanoid release, apoptosis and T-lymphocyte tumor infiltration in a murine mammary gland adenocarcinoma. Prostaglandins Leukot. Essent. Fat. Acids 2007, 77, 21-28, doi:10.1016/j.plefa.2007.05.005.

9. Schley, P.D.; Jijon, H.B.; Robinson, L.E.; Field, C.J. Mechanisms of omega-3 fatty acid-induced growth inhibition in MDA-MB-231 human breast cancer cells. Breast Cancer Res. Treat. 2005, 92, 187-195, doi:10.1007/s10549-005-2415-z.

10. Song, K.-S.; Jing, K.; Kim, J.-S.; Yun, E.-J.; Shin, S.; Seo, K.-S., Park, J.-H.; Heo, J.-Y.; Kang, J.X.; Suh, K.-S.; et al. Omega-3-Polyunsaturated Fatty Acids Suppress Pancreatic Cancer Cell Growth in vitro and in vivo via Downregulation of Wnt/Beta-Catenin Signaling. Pancreatology 2011, 11, 574-584, doi:10.1159/000334468.

11. Segura-Campos, M.R.; Ciau-Solís, N.; Rosado-Rubio, G.; Chel-Guerrero, L.; Betancur-Ancona, D. Chemical and functional properties of chia seed (Salvia hispanica L.) gum. Int. J. Food Sci. 2014, doi:10.1155/2014/241053.

12. Ullah, R.; Nadeem, M.; Khalique, A.; Imran, M.; Mehmood, S.; Javid, A.; Hussain, J. Nutritional and therapeutic perspectives of Chia (Salvia hispanica L.): A review. J. Food Sci. Technol. 2016, 53, 1750-1758, doi:10.1007/s13197-015-1967-0.

13. Riss, T.L.; Moravec, R.A.; Niles, A.L.; Duellman, S.; Benink, H.A.; Worzella, T.J.; Minor, L. Cell Viability Assays. Assay Guid. Man. 2013, 114, 785-796, doi:10.1016/j.acthis.2012.01.006.

14. Mosmann, T. Rapid colorimetric assay for cellular growth and survival: Application to proliferation and cytotoxicity assays. J. Immunol. Methods 1983, 65, 55-63, doi:10.1016/0022-1759(83)90303-4.

15. Porras-Loaiza, P.; Jiménez-Munguía, M.T.; Sosa-Morales, M.E.; Palou, E.; López-Malo, A. Physical properties, chemical characterization and fatty acid composition of Mexican chia (Salvia hispanica L.) seeds. Int. J. Food Sci. Technol. 2014, 49, 571-577, doi:10.1111/ijfs.12339.

16. Bratton, B.A.; Maly, I.V.; Hofmann, W.A. Effect of polyunsaturated fatty acids on proliferation and survival of prostate cancer cells. PLoS ONE 2019, 14, e0219822, doi:10.1371/journal.pone.0219822.

17. Chamberland, J.P.; Moon, H. Down-regulation of malignant potential by alpha linolenic acid in human and mouse colon cancer cells. Fam. Cancer 2014, 14, 25-30, doi:10.1007/s10689-014-9762-z.

18. Wiggins, A.K.A.; Kharotia, S.; Mason, J.K.; Thompson, L.U. $\alpha$-Linolenic Acid Reduces Growth of Both Triple Negative and Luminal Breast Cancer Cells in High and Low Estrogen Environments. Nutr. Cancer 2015, 67, 1001-1009, doi:10.1080/01635581.2015.1053496.

19. Connolly, J.M.; Liu, X.H.; Rose, D.P. Dietary linoleic acid-stimulated human breast cancer cell growth and metastasis in nude mice and their suppression by indomethacin, a cyclooxygenase inhibitor. Nutr. Cancer 1996, 25, 231-240, doi:10.1080/01635589609514447.

20. Reyes, N.; Reyes, I.; Tiwari, R.; Geliebter, J. Effect of linoleic acid on proliferation and gene expression in the breast cancer cell line T47D. Cancer Lett. 2004, 209, 25-35, doi:10.1016/j.canlet.2003.12.010.

21. Rodriguez-Monterrosas, C.; Diaz-aragon, R.; Cortes-Reynosa, P. Linoleic acid induces an increased response to insulin in MDA-MB-231 breast cancer cells. J. Cell Biol. 2018, 119, 5413-5425, doi:10.1002/jcb.26694.

22. Sharma, R.; Kaushik, S.; Shyam, H.; Agarwal, S.; Kumar, A. Neem Seed Oil Induces Apoptosis in MCF-7 and MDA MB-231 Human Breast Cancer Cells. Asian Pac. J. Cancer Prev. 2017, 18, 2135-2140, doi:10.22034/APJCP.2017.18.8.2135.

23. Hardman, W.E.; Ion, G. Suppression of Implanted MDA-MB 231 Human Breast Ca.ncer Growth in Nude Mice by Dietary Walnut. Nutr. Cancer 2008, 60, 666-674, doi:01635580802065302.

24. Cho, K.; Mabasa, L.; Park, C.S. Canola Oil Inhibits Breast Cancer Cell Growth in Cultures and in vivo and Acts Synergistically with Chemotherapeutic Drugs. Lipids 2010, 45, 777-784, doi:10.1007/s11745-010-3462-8.

25. Truan, J.S.; Chen, J.; Thompson, L.U. Flaxseed oil reduces the growth of human breast tumors (MCF-7) at high levels of circulating estrogen. Mol. Nutr. Food Res. 2010, 54, 1414-1421, doi:10.1002/mnfr.200900521.

(C) 2020 by the authors. Licensee MDPI, Basel, Switzerland. This article is an open access article distributed under the terms and conditions of the Creative Commons Attribution (CC BY) license (http://creativecommons.org/licenses/by/4.0/). 